\title{
FLT3LG wt Allele
}

National Cancer Institute

\section{Source}

National Cancer Institute. FLT3LG wt Allele. NCI Thesaurus. Code C49785.

Human FLT3LG is located in the vicinity of $19 q 13.3$ and is approximately $12 \mathrm{~kb}$ in leng th.

This allele, which encodes Fms-related tyrosine kinase 3 ligand protein, plays a role in the stimulation of hematopoietic progenitor cells. 